\title{
ФОРМУВАННЯ ХРИСТИЯНСЬКОГО СВІТОГЛЯДУ В ДАВНІЙ РУСІ: ПРОБЛЕМА «ДВОВІР'Я»
}

\section{С.А.Батрак, О.П. Батрак, І.Л. Рогачова}

Вивчаючи процеси взаємодії різних традицій в рамках давньоруської культури, вченими напрацьовано величезний корпус фахової літератури. Особлива увага приділялась періоду прийняття християнства і залученню Давньої Русі до нових духовних цінностей. Актуалізація дискусії по цій проблемі полягає у тому, наскільки адекватно термін «двовір'я» може відображати «роздвоєнність» («дуалізм») давньоруської культури, і чи існував поряд із християнським «язичницький світогляд руського середньовіччя»? В цій статті ми ставимо за мету розглянути зазначену проблему через призму історіософської концепції Біблії щодо людності, яка залучалась до християнства з язичницького середовища.

Більшість вчених вважає, що ця взаємодія сформувала на київському грунті XI - поч. XIII ст. синкретичний релігійно-світоглядний християнсько-язичницький варіант релігійності ${ }^{1}$. О. Моця зазначає, що саме «цей перехідний етап в зміні релігійних систем вже в XI ст. Феодосій Печерський назвав двовір'ям» ${ }^{2}$. Вивчаючи це явище давньоруської культури «О.В. Чернецов, - пише О. Моця, - прийшов до висновку, що до двовір'я можуть бути віднесені: а) одночасне звернення до християнських та нехристиянських надприродних персонажів й інші форми змішування різнорідних релігійних елементів; б) використання християнами елементів язичницької обрядовості й фразеології; в) присвоєння персонажам християнської міфології якостей язичницьких нижчих та вищих божеств; г)

\footnotetext{
${ }^{1}$ Iсторія релігії в Україні: у 10 т. Українська ред. проф. П. Яроцького. - К., 1997. Т.2.- С.30-38.; Рыбаков Б.А. Язычество Древней Руси.-М., 1987.; Милъков B.В. Пилюгина Н.Б. Христианство и язычество: проблема двоеверия // Введение христианства на Руси. - М., 1987. - С. 263-273.

${ }^{2}$ Моця О. Культура «мовчазної більшості» епохи Київської Русі // Україна в Центрально-Східній Європі . Студії з історії XI-XVII століть. Випуск 3. - К., 2003. - С. 46
} 
звернення до язичницьких персонажів і мотивів в явно християнському середовищі» ${ }^{3}$.

При цьому наголошується, що «двовір'я на Русі - $є$ прямим наслідком затягнувшоїся християнізації» ${ }^{4}$. Що двовір'я як синкретизм язичництва і православ'я на Русі з'явилось ще до 988 р. У зв'язку з цим християнські ідеї були вже відомі частині слов'ян в IX-X ст. Наводиться факт клятви у 944 р. частини дружини на чолі з князем Ігорем біля Перуна під час підписання русько-візантійського договору, а частини воїнів в соборній церкві св. Іллі на Подолі. Тому синкретизм старих і нових вірувань мав місце в ідеологічних поглядах частини русів вже в IX-X ст., що і проявилось в поховальному обряді (декого ховали за обрядом інгумації в супроводі інвентаря та з насипанням кургану над небіжчиком). «Тож для $\mathrm{IX}-\mathrm{X}$ ст. слід говорити про християнство в язичництві, а для XI-XIII ст. про язичництво в християнстві» 5 .

Дослідники, які представляють майже прямо протилежну точку зору, звертають увагу на те, що сам термін «двовір'я» практично не визначено. Що різні автори використовують його в самих різних значеннях. Як правило, під ним мають на увазі «оязичування» християнства. Але, чи могло бути саме східнослов'янське язичництво єдиним визначальним фактором формування самобутності руського християнина. «Оскільки, - зауважує I.Н. Данілевський, - сам термін «язичництво»- (фактично - нехристиянство) не зовсім визначений, то такий підхід припускає вільне розширення явищ «двовір'я» 6 .

Наприкінці 80-х років XX ст. в публіцистичній літературі робились спроби уточнити зміст поняття «двовір'я». «Зокрема, - пише М.П.Новіков, - Д.С. Ліхачов в ряді статей стверджує, що двовір'я взагалі не може бути: або одна віра, або ㄲï нема. .. що саме язичницькі звичаї набули етичного християнського забарвлення і християнство вбирало в себе різні язичницькі звичаї» ${ }^{7}$. М. Новіков припускав, «що ні Є.Є. Голубинський, ні М.М.Гальковський, ні Є.В.Анічков, ні Г.В.Флоровський не розглядали «двовір'я», яке вони вважали специфічною особливістю руського православ'я перших віків, як існування в свідомості неофітів двох незалежних систем релігійних уявлень. Такий дуалізм в принципі неможливий» ${ }^{8}$.

«Якби все зводилось до «двовір'я»,- пише М.I. Толстой, - тобто до двох компонентів, до двох джерел слав'янської народної духовної куль-

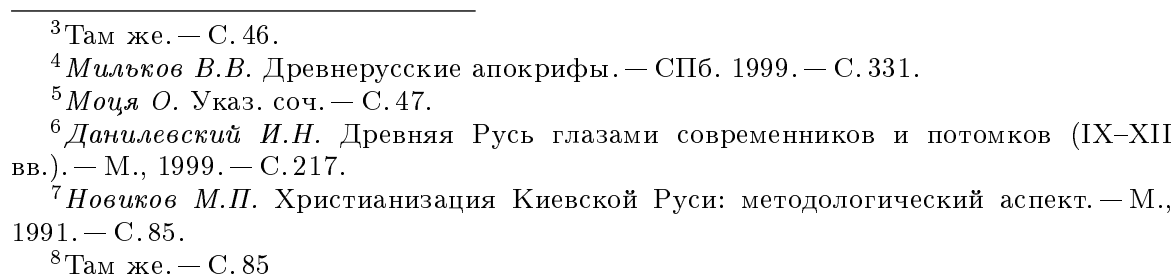


тури в кінці 1-го і на початку 2-го тисячоліття нашої ери, культури, яка мала послідовний і безперервний розвиток до наших днів, питання з'ясування елементів слов'янських дохристиянських язичницьких старожитностей вирішувалося б відносно просто. Все, що залишалося б, виключивши християнські інститути, риси і особливості, добре відомих за багаточисельними письмовими свідоцтвами, можна було б віднести на рахунок дохристиянського язичництва, пояснити як його продовження, розвиток чи релікти» ${ }^{9}$. «Але, - зазначає автор, - якщо розглядати це питання з генетичної точки зору, з точки зору витоків народної духовної культури, доведеться визнати, що таких витоків чи джерел було більше двох християнського і язичницького. Існувало ще третє джерело, багато в чому прийняте слов'янами разом чи майже одночасно з християнством. Це народна і міська культура, яка розвивалась і в Візантії, і зокрема на Заході. Так проникали в слов'янське середовище елементи пізньої античності-еллінства, мотиви близькосхідних апокрифів, східного містицизму і західної середньовічної книжності, які ... надавали всій слов'янській культурі епохи минувшого тисячоліття певне обличчя, повноту і різнобічність їі зовнішніх, формальних і внутрішніх - ідеологічних і змістовних - проявів сутності» ${ }^{10}$. Мова йде, за термінологією М.І. Толстого про «третю» культуру, культуру ахристиянську, не християнську, але далеко не завжди антихристиянську. Ця культура була протиставлена християнству, подібно тому, як в слов'янському середовищі протиставлялось християнство та язичництво. А відречена література (мова йде про так звану апокрифічну літературу) як раз і була носієм цієї «третьої» культури. «З деякою обережністю чи умовністю, - пише М.I. Толстой, - до елементів окресленої нами «третьої» культури можна віднести юродство (яке пізніше стане одним 3 церковних інститутів), скоморошество (яке періодично буде то переслідуватися, то визнаватися владою), міську карнавальну, ярмарочну і лубочну культуру, дожившу до нашого століття, яка мала свою автономну еволюцію і свої локальні шляхи розвитку» ${ }^{11}$. I.M. Данілевський до явищ «третьої» культури відносить також багаточисельні згадки «бесовских игр», «сотонинских песен» та «плясаний», наголошуючи, що без додаткових пошуків, які б дозволили повніше поновити їх сутність, не дає достатньо підстав для віднесення їх до язичницьких обрядів» ${ }^{12}$. У зв'язку з цим, В.Я. Петрухін наголошував, що в докорах давньоруських книжників «християнам двоеверно живущим», саме двовір'я розумілось як «потворство новій релігійній творчості новонаверне-

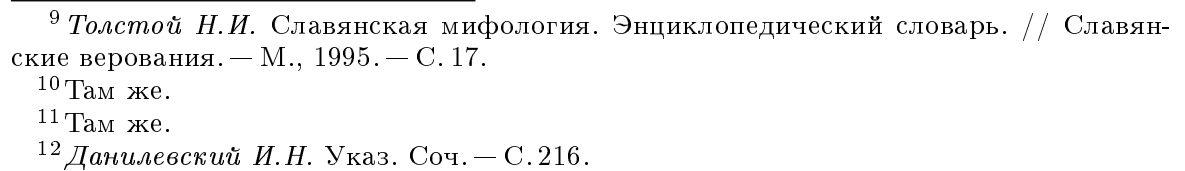


них християн, які прагнули за допомогою нових прийомів та нових приурочень задовольняти старим, закоріненим в свідомості потребам віри і культа: викрити ці старі потреби як язичницькі прагнули давньоруські книжники» ${ }^{13}$. Є.В. Анічков бачив в основі цих культів «сільськогосподарську релігію, яка зверталась безпосередньо до стихій, тобто до самої природи» ${ }^{14}$ (язичницькі боги тут ні до чого). В.Я. Петрухін відмічає, що «в сучасній історичній антропології таким чином розрізняються магія та релігія: «Релігія - форма олюднення світу, надання йому антропоморфічних рис і властивостей; релігія пов'язана з «уособленням» цих ознак і наділенням ними божеств. Магія ж-так би мовити «оприроднювання» людини, яка в собі виявляє якості всього іншого світу і сприймає себе як органічну його частину» ${ }^{15}$. «Руські люди, - пише автор посилаючись на М.М. Гальковського, - зазвичай не помічали свого двовір'я: народна маса вважала себе істино християнською». Термін «двовір'я» виявлявся таким чином, включеним в систему протиставлення «істинної віри» та «іновір'я» та традиційної магії, в систему, притаманну «релігійному ригоризму» давньоруських книжників, але не руській традиційній культурі, усвідомлюючій себе цілком християнською» ${ }^{16}$. Побутове християнство, зазначав M.I. Толстой, - дало язичницьким міфологічним персонажам i уявленням статус «нечистої сили», негативного духовного начала, яке протиставилось силі «хрещеній», чистій і переповненій святості. Образно говорячи, в народній фольклорній уяві небо опинилось зайнятим силами небесними, праведними і божественими, ад, підземний світ, болота, ями і рівчаки - силами нечистими і темними, а земля - місце боротьби двох світів і начал, і людина, і ㄲï душа-зосередження цієї боротьби. Сили ці все ж не рівномірні і не рівновеликі, оскільки воля Божа і проведіння Боже володарює над усім і визначає все. Таке народне християнське світобачення, типове для слов'ян обох конфесій - православної і католицької, не можна вважати і називати двовір'ям, оскільки воно цільне і являє собою єдину систему вірувань» ${ }^{17}$. «Сама система давноруських вірувань, - підкреслює В.Я. Петрухін, - в генитичному плані являла собою скоріше «троєвір'я» (в термінах М.І. Толстого, 1996): «канонічний»культ був невідокремленим від «наносного» не канонічного, і обидві ці форми взаємодіяли 3 «фольклорними» міфічними практиками» ${ }^{18}$.

У зв'язку з цим, «все не св'ященне» в давньоруській культурі було

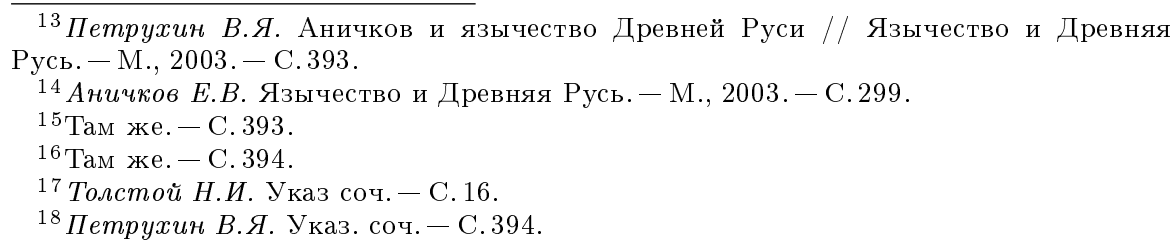


не просто «профанним»- воно було блюзнірським в парадигмі «святої» мови: «не священий» фольклор, народна творчість і звичаї приймались як бісовське скоморошество і виявлялося в давньоруських повчаннях як «язичницькі» - не залежно від того, містили чи вони в дійсності язичницькі пережитки. Не дивлячись на середньовічні церковні обвинувачення руських християн у двовір'і, які некритично були сприйняті і сучасними дослідниками, можна стверджувати, що язичницькі пережитки на Русі були асимільовані, як і всюди у Європі, культами християнських святих» 19 .

Не можна не погодитись 3 думкою M.I. Толстого, що така неоднозначна позиція у авторів базується на різних підходах. В одному випадку «двовір'я» чи навіть «троєвір'я» можна виявити лише при діахронічному підході, шукаючи відповідь на питання з яких саме різнорідних пластів складається чи складалася слов'янська народна духовна культура. При синхронно-структуральному розгляді цього явища можна говорити про цілісність релігійно-міфологічних народних уявлень, про діалектне, народне єдиновір'я ${ }^{20}$.

Серед накопиченого дослідниками матеріалу по зазначеній проблемі, зокрема, у відомій монографії Є.В.Анічкова «Язичництво і Давня Русь» зроблено текстологічний аналіз давньоруських текстів «Слово некоего Христолюбца», «Слово о том како погани суще языци кланялися идолом»; кожен з яких дійшов до дослідників в декількох різних списках. Дослідник зміг виділити багаточисельні вставки-коментарі південнослов'янські за походженням. Поняття «двовір'я» пов'язувалось з ідолопоклонством в «Слове некоего христолюбца, ревнителя по правой вере». За реконструкцією Є.В. Анічкова, «двоеверно живущими» оголошувались «попы и книжники», які не виконували церковні правила, що стосувалися трапези. Тут ще не йде мова ні про язичництво, ні про іновір'я «двовірців» ${ }^{21}$. В ідолослужінні звинувачивались і виконавці традиційних шлюбних обрядів. . ${ }^{22}$. Але у вставках редактора язичницькі ідоли отримують імена давньоруських язичницьких богів: «двоеверцы веруют в Перуна, и в Хърса, и в Сима, и в Ръгла, и в Мокошь и в вилы...» ${ }^{23}$. Ця вставка, на думку дослідників, не могла з'явитися раніше поч. XII ст. Теж саме можна сказати і про «Слово о том, како погани суще языци кланялися идолом» ${ }^{24}$. На думку Є. Анічкова, звинувачення церковниками в ідолослужінні підмінено боротьбою з старими традиційними язичницькими

\footnotetext{
${ }^{19}$ Там же.- С. 398.

${ }^{20}$ Петрухин В.Я. Древняя Русь: Народ. Князья. Религия. - М.: Т.1. 2000.- С. 289.

${ }^{21}$ Аничков Е.В. Указ. соч. - С. $127-138$.

${ }^{22}$ Там же. - С. 266.

${ }^{23}$ Там же. - C. $374-377$.

${ }^{24}$ Там же. - C. $384-385$
} 
культами (магією), які були зорієнтовані до стихій, тобто до самої природи, яка була нерозривно пов'язана з сільськогосподарською діяльністю, а не до богів ${ }^{25}$. В своєму дослідженні Є. Анічкову вдалося виявити книжні витоки давньоруського «двовір'я». Вперше цей термін було використано Феодосієм Печерським в «Слове о вере христианской и латинской» (1069 р.) - по відношенню до християн, які могли перейти з православного до латинського обряду. В подальшому ж «двовір'я» руських книжників - це «двовір'я», яке прийшло разом з християнством, двовір'я наносне, що потрапило на Русь $з$ відреченими книгами (апокрифами)... ${ }^{26}$. Є.В. Анічков писав: «Но раз основа язычества определена, и категорически сказано,что язычество есть поклонение обоготворяемых сил природы, то каким образом, например, запрещаемое христианам кровоядения, употребление в пищу удавлины, „в племени поятие“, т.е. женитьбу с состоящими в родстве и т.д. мы сочтем за двоеверіе?» 27 .

Як на наш погляд, відповідь міститься в Дії святих апостолів. Десь, у 51-му році відбувся апостольський собор а Єрусалимі. Вирішувалося питання, чи потрібно проводити обряд обрізання й дотримуватись Закона Мойсея серед язичників, які приймали християнство. Рішенням апостольського собору було таке: «Ибо угодно Святому Духу и нам не возлагать на вас никакого бремени более, кроме сего необходимого: воздерживаться от идоложертвенного и крови, и удавления, и блуда, и не делать другим того, чего себе не хотите; соблюдая сие, хорошо сделаете.» (Деян. 15: 2829) (Наводимо переклад російською мовою, оскільки українською мовою текст викладено неповністю). Необхідними названі тільки три критерії: стримуватися від ідольських жертов, крові тварин і задушенини (в Старому Заповіті в це поняття вкючається м'ясо тварин, з яких не випущено кров, померлих від хвороб, чи убитих іншим звіром, чи загинувших в результаті стихійного лиха); утримуватися від блуду; братолюбиве відношення до людей.

Про недопустимість блуду багато сказано в Новому Заповіті. Цей гріх ставиться в один ряд з вбивством. Але про ідоложертвене та кров, ні про задушенину Ісус Христос прямо не говорить. Від цього всього застерігає Старий Заповіт. Навіть там, де апостоли наказують дотримуватися певної норми поведінки - не робити іншим того, чого собі не бажаєте, вони мають на увазі не Євангеліє. Христос призиває до більшого-возлюбити ворогів своїх, до самопожертвування за друзів своїх (Ів. 15: 13). Це свідчить про те, що апостоли не ставили завдання короткого викладення Євангельського вчення про нравственність, але керувались чимось іншим. Абсолютно ясно, що вибрані три критерія із Закона Мойсея ро-

${ }^{25}$ Там же. - С. 299
${ }^{26}$ Там же. - С. 282

${ }^{27}$ Там же. - C. 123 
зумілися як закон, написаний в серцях (Ієр. 31: 33; Євр. 10, 16) рівно обов'язковий для всіх народів. Виконання саме цього закону дає можливість язичникам вірно сприйняти і виконувати Євангеліє Христове. (Бо зволилось Духові Святому і нам, - тягару вже ніякого не накладати на вас, окрім цього необхідного). З'ясуємо, який зміст вкладався в кожен критерій апостольським собором. Щодо ідоложертвенної заборони, то вона нерозривно була пов'язана з відмовою від ідолопоклонства (Вих. 20: 3-6; 20: 23; 34: 14; Второз. 4: 15-28). Тобто, новохрещений язичник повинен був усвідомити, що кумири, яких він вважав раніше своїми богами $€$ творінням людських рук, що у всесвіті володарює могутніший Бог, яким створено весь світ і природа, яку обожнювали язичники, і сама людина. Забороняючи нечисту, скверну їжу, особливо крові, мертвечини і задушенини, передбачалось закласти підвалини для здорового духовного життя. В Старому Заповіті Господь говорить до богообраного Ізраїля: і не будете їсти м'яса, розшарпаного в полі, - псові кинете його! (Вих. 22: 30); крови кожного тіла ви не будете їсти, бо життя кожного тіла - кров його вона (Лев. 17: 14); тільки будь обережним, щоб не їсти крови, бо кров-вона душа, і ти не будеш їсти душі разом з м'ясом (Второз. 12: 23). Заборону не їсти крові тварин покладено було для всього людства в особі Ноя і його роду: Усе, що плазує, що живе воно, -буде вам на їжу. Як зелену ярину - Я віддам вам усе. Тільки м'яса з душою його, цебто з кров'ю його, не будете ви споживати (Бут. 9: 3-4). Відомо, що ці заборони були підтверджені рішеннями 7-ми Вселенських соборів, правилом 63-м. В разі якщо хтось із священослужителів буде їсти м'ясо у крові, чи мертвечину, - да буде вивержений (із сана). Якщо це зробить мирянин, - да буде відлучений. Що стосується пункта стримуватися від блуду (перелюбу), то саме через таку заборону створювалися умови для переходу до моногамної сім’ї, де простежується онтологічна триєдність Триєдиного Бога і сім'ї: чоловік-дружина-дитина. Настановою не робити іншим того, чого собі не хочете переслідувалась мета формувати свідоме розуміння того, що всі люди створені по образу і подобі Божій, тобто єдині у своїй природі і багаточисельні в особистостях. У зв'язку з цим, образа, що нанесена іншій людині, - це злочин і проти Бога, і проти себе. «Хто виллє кров людську з людини, то виллята буде його кров, бо Він учинив людину за образом Божим» (Бут. 9: 6).

Таким чином, можна констатувати, що рішенням Ієрусалимського собору святих апостолів було зроблено поступку язичникам, щоб з самого початку створити моральну основу новому християнському світогляду. А потім поетапно переходити до більш складного завдання - навертати до істинного духовного життя в благодаті. Не тільки визнати всемогутнього Бога, але й змінити язичницьке світосприйняття, якому буде притаманне інше світобачення. «Так характерно в этом случае,- писав 
Є.В.Анічков, - обращение к слушателям одной из древних проповедей: „Братие! Первое приимьше святое крещение правы веры, потом научимъся боятись Бога и творити волю Єго“» ${ }^{28}$.

Звертає на себе увагу і те, що в «Повісті временних літ» руський літописець описуючи історію слов'янських племен, акцентує увагу на ті ж самі нравственні критерії, які були окреслені апостольським собором. «Усі племена мали ж свої обичаї, і закони предків своїх, і заповіти, кожнесвій норов. Так поляни мали звичай своїх предків тихий і лагідний, і поштивість до невісток своїх, і до сестер, і до матерів своїх, а невістки до свекрів своїх і до діверів велику пошану мали. I весільний звичай мали вони: не ходив жених по молоду, а приводили ㄲï ввечері; а назавтра приносили (для її родини те), що за неї дадуть. А деревляни жили подібно до звірів, жили по-скотськи: і вбивали вони один одного, і їли все нечисте, i весіль у них не було, а умикали вони дівчат коло води. А радимичі, і вятичі, і сіверяни один обичай мали: жили вони в лісі, як ото всякий звір, їли все нечисте, і срамослов'я було в них перед батьками і перед невістками. I весіль не бувало в них, а ігрища межи селами. I сходилися вони на ігрища, на пляси і на всякі бісівські пісні, і тут умикали жінок собі, - з якою ото хто умовився. Мали ж вони по дві і по три жони. А коли хто вмиравчинили вони тризну над ним, а потім розводили великий вогонь i, поклавши на вогонь мерця, спалювали його. А після цього, зібравши кості, вкладали їх у невеликий посуд і ставиди на придорожньому стовпі, як це роблять вятичі й нині. Сей же обичай держали і кривичі, й інші погани, не відаючи закону божого, бо творили вони самі собі закон» ${ }^{29}$. Потім літописець цитує хроніку Георгія Амартола, де Георгій звертає головну увагу на тіж самі сторони життя у інших народів: відношення до людей, до їжі і до подружного життя. Закінчується опис літописцем коротким аналізом свого часу. «Так само оце й нині, при нас, половці держать закони предків своїх: кров проливали і вихвалялися цим. I їдять вони мертвечину і всяку нечисть, хом'яків і ховраків. А за себе беруть вони мачух своїх і ятрівок, і інші сповняють обичаї отців своїх. А ми ж, християни,- оскільки єсть земель, що вірують у святую трійцю, і в єдине хрещення, і в єдину віру, - закон маємо один, оскільки ми в Христа охрестилися і в Христа втілились» 30 .

Очевидно, що літописець знав про рішення апостольського собору і саме таким коротким екскурсом показав яким шляхом відбувалася християнізація в руській землі. В літописі ми знаходимо навіть виокремлені книжником, Звичайно з точки зору літописця, хронологічні рамки ета-

\footnotetext{
${ }^{28}$ Там же.- С. 107

29 Лimonuc Руський. За Іпатським списком / Переклав Л. Махновець. - К., 1990. C. 8-9.

${ }^{30}$ Там же, - C. 10
} 
пів залучення слов'ян до християнської віри. Перший етап - кінець $\mathrm{X}-$ початок XI ст., другий етап-середина XI ст., третій етап-до початку XII ст. Перший етап літописець пов'язує з ім'ям князя Володимира Святославича, який «хрещенням просвітив». Другий-з ім'ям Ярослава Володимировича, який «засіяв книжними словами серця віруючих людей». До третього етапу літописець відносить своїх сучасників - «а ми пожинаєм, учення приймаючи книжнеє». «Бо як ото хто-небудь землю зоре, а другий засіє, а інші пожинають і їдять поживу вдосталь...» ${ }^{31}$.

Зафіксовано в літописі і етапи ідейної зрілості християн, а також той мінімум вимог, який не тільки дає право називатись християнином, але й виміряти свої дії, життя з точки зору і християнської моралі, і віри, тобто, не тільки знати Бога, але й почитати Його. Такий шлях богопізнання для загальної людності тривав понад 100 років. I тільки під 1102 роком літописець описуючи знамення на небі, керуючись повчанням преподобного Феодосія «Про кари Божії», вперше до загальної більшості застосував слово - благочестиві, тобто - набожні. «А сі знамення бачачи, благочестиві люди з зітханням і з слізьми молилися Богу, аби обернув Бог знамення сі на добро. Бо знамення бувають або ж на добро, або ж на зло. І от сі знамення були на добро» ${ }^{32}$. Тоді, як у 1064 році теж сталося знамення, але не на добро. «За гріхи наші напустив Бог на нас поганих, і побігли руські князі, і перемогли половці» ${ }^{33}$. Далі, повністю викладено повчання Феодосія Печерського «Про кари божії» ${ }^{34}$.

Дослідників дивує, що навіть на рубежі XII і XIII ст., за виключенням чернецтва, в літописних і позалітописних джерелах серед представників світської влади нема аскези. Наприклад, в «Поученні» Володимира Мономаха, для спасіння душі достатньо трьох діл: «Як отець, що, чадо своє люблячи, поб'є його і знову пригорне його до себе, так ото і Господь наш навчив нас, як добути над врагом-дияволом побіду: трьома ділами добрими можна позбутись його і побідити його - покаянням, сльозами і милостинею (виділ. авт.). I то вам, діти мої, не тяжка заповідь божа, бо тими ділами трьома можна позбутися гріхів своїх і царства небесного не лишитися. Тож, бога ради, не лінуйтеся, я благаю вас, не забувайте трьох діл тих. Бо не $€$ важкі вони. Се ні самотина, ні чернецтво, ні голод, як інші добрії люди терплять, а малим ділом сим досягти можна милості божої» ${ }^{35}$. Саме такий тріадний мінімум вимог, щоб досягти небесного царства, літописець фіксує під 1015 роком по смерті князя Володимира. «Бо якщо раніш, у невігластві були в нього деякі гріхи, то потім споку-

\footnotetext{
${ }^{31}$ Там же. - C. 89

${ }^{32}$ Там же. - С. 157.

33 Там же. - C. 104-105.

${ }^{34}$ Там же. - C. 104-105.

${ }^{35}$ Там же. - С. 456
} 
тувалися вони покаянням і милостинями...Сей же Володимир помер у сповіданні щирому, покаянням спокутувавши гріхи свої і милостинями, що $є$ ліпшим над усе» 36 .

Цікавим $є$ і те, якою молитвою радить Володимир Мономах перемогти диявола і позбавитись гріха. «Навіть і на коні їздячи, коли не буде у вас ні 3 ким діла і якщо інших молитов не умієте ви мовити, то «господи, помилуй», благайте безперестану потай, - бо ся молитва єсть ліпша од усіх» ${ }^{37}$. Характерною для такого «мінімуму» $є$ і подія під 1103 роком. Готуючись до бою з половцями «Руські князі і вої молили бога і обітниці воздавали богові і пречистій матері Його - той кутею, а той милостинею убогим, а ті пожертвами монастирям» ${ }^{38}$. Літописець, християнин, не посоромився написати, що обітницю богові воздавали кутею. Навпаки, далі записав: «I велике спасіння вчинив бог у той день благовірним князям руським і всім християнам, а над ворогами нашими дав побіду велику» 39 .

Осмислюючи саме під таким кутом зору духовне переродження колишніх язичників, можна констатувати.

По-перше, починаючи з часів Володимира Святославича (не виключаємо, що така система заходів пов'язана з кирило-мефодіївською традицією і вченням апостола Павла, який проповідував в Моравських землях, і звідкіля наш літописець торував шлях), керуючись рішенням апостольського собору в Єрусалимі, найголовніша увага була приділена релігійноморальному фактору. Поетапність заходів була спрямована на формування відповідних духовних цінностей християнського світогляду.

По-друге, враховуючи, що в Давньоруській державі церковна влада була підпорядкована світській владі, ідейний рівень духовного зростання християн не міг не корегуватися інтересами князя і його оточення (звідсіля - надмірна м'якість давньоруського церковного права). Тому, християнство руського середньовіччя багато в чому було неортодоксальним ахристиянським. На нашу думку, відбувався складний процес симбіозу християнства і язичництва, а не їх синкретизм.

По-третє, як на наш погляд, давньоруські книжники орієнтувалися на історіософську концепцію Біблії; осягаючи свою історію через цю історіософію, включаючи історію слов'ян Давньої Русі у всесвітню історію християнських народів, бачили себе новими людьми - православними християнами, а не іновірцями, чи то двовірцями.

Вважаємо, що давньоруська культурна спадщина повинна осмислюватися через методологічну систему, зорієнтовану на категоріальне русло християнського світогляду того часу, а не сучасних критеріїв і оцінок.

\footnotetext{
${ }^{36}$ Там же. - C. $75-76$

37 Там же - C. 457

${ }^{38}$ Там же. - C. 158

${ }^{39}$ Там же. - С. 159
} 